\title{
Legal Lobbying: The Evolving (But Hidden) Role of Lawyers and Law Firms in the EU Public Affairs Market
}

\author{
Emilia Korkea-aho* (i) \\ Faculty of Social Sciences and Business Studies and Law School, University of Eastern Finland, Joensuu, Finland
}

(Received 03 February 2020; revised 30 September 2020; accepted 01 October 2020)

\begin{abstract}
There is an increasing involvement of lawyers and law firms in public affairs through activities that are aimed at influencing legislative and regulatory developments. Law firms offer services which can be regarded as lobbying, and yet, to the detriment of transparent policy-making, they are reluctant to register in the European Union Transparency Register (EUTR) and provide information about their activities. As growing attention is paid to the need to regulate lobbying at the EU and Member State levels, the question arises as to whether and to what extent such regulatory framework should also cover certain services provided by law firms, that is, legal lobbying. This Article charts the phenomenon of legal lobbying and its regulation in the EU context. It shows how the EUTR attempts to distinguish between legal services and lobbying by defining two lawyer roles: a legal expert, and an advocate. These roles allow the possibility to pinpoint two unresolved issues associated with legal lobbying: the scope of professional secrecy, and the meaning of the legal advice exception. An important conclusion is that regulatory clarification is necessary to resolve ambiguities and broadly address the implications that legal lobbying raises in terms of transparent and legitimate law-making processes.
\end{abstract}

Keywords: EU law; lobbying; legal profession; transparency; legal expertise; professional secrecy

\section{A. Introduction}

In the past decade, the number of states and transnational political institutions, such as the European Union, interested in legislating lobbying-political advocacy by interest groups-has grown. ${ }^{1}$ One of the main functions of lobbying regulation, often expressly stated in the text of relevant legislation, is the enhanced transparency around decision-making processes. ${ }^{2}$ The establishment of EU and national transparency registers for firms and actors involved in lobbying is

\footnotetext{
${ }^{*}$ Associate Professor of European Law and Legislative Studies, University of Eastern Finland Law School, Academy of Finland Research Fellow. I thank Trevor Clark, Panu Minkkinen, Andreea Nastase, Jo Shaw, Hilary Sommerlad, Ben Yong, and anonymous reviewers for encouraging and helpful discussions and comments.

${ }^{1}$ See Raji Chari, John Hogan, Gary Murphy \& Michele Crepaz, Regulating lobbying (2d ed. 2019).

${ }^{2}$ Andrew Lansley, Member, House of Lords of the United Kingdom, Remarks at the Second Reading of the Transparency of Lobbying, Non-Party Campaigning and Trade Union Administration Bill (Sept. 3, 2013), https://publications. parliament.uk/pa/cm201314/cmhansrd/cm130903/debtext/130903-0001.htm\#13090336000002. At the EU level, see the 2014 Interinstitutional Agreement (IIA) establishing the EU's Transparency Register (EUTR) that specifically notes, paraphrasing Article $11 \mathrm{TEU}$, that its purpose is to "maintain an open, transparent and regular dialogue with representative associations and civil society." (emphasis added).
} 
premised on the idea that transparency is central to accountability and that the public should be able to see how lobbyists seek to influence the political system. ${ }^{3}$

As growing attention is being paid to the need to regulate lobbying at the EU and Member State levels, the question is raised as to whether and to what extent such regulatory frameworks should also cover certain services provided by law firms. Involvement of lawyers and law firms in public affairs is increasing through a number of activities and services that are directly or indirectly aimed at influencing regulatory and legislative developments and are, therefore, not dissimilar to those performed by lobbying firms. Large Brussels-based law firms all offer services aimed at influencing legislative developments: Covington \& Burling LLP under the heading of "Public Policy"; 4 Allen \& Overy with the label "Political Law"; 5 and Clifford Chance under the description "Public Policy", with the promise that they "can help you to engage in the political and law making process to ensure that the needs of your business are understood and supported." Some law firms even see lobbying as their unique selling point. Alber \& Geiger describes itself as a "political lobbying powerhouse," explaining how the law firm that houses former EU officials, leading politicians, and high-profile attorneys "combine[s] legal expertise with lobbying knowledge."7 In the firm's view, it is specifically their legal expertise that "sets [them] apart" from others in the lobbying market. ${ }^{8}$ It does not seem an overstatement to suggest that European and global lawyering "consists largely of ... lobbying legislators and regulators."

This more prevalent role of law firms and lawyers in the public affairs space has sparked an intense regulatory controversy. EU and in some cases also national transparency registers require those who offer lobbying services to register and disclose information about their activities, yet law firms escape registration by claiming professional secrecy concerns. The seemingly technical question of the interpretation of the scope of professional secrecy fueling the regulatory controversy, however, masks broader questions. Where do the boundaries between legal services and lobbying lie? Is it possible to distinguish the role of a lawyer from that of a lobbyist? Is there an actor identifiable as a "lawyer-lobbyist"? The difficulties in distinguishing clearly when certain services provided by law firms are classified as legal services or when they instead touch the realm of influencing public policy are not insignificant. The problems posed by these difficulties in distinguishing one from another raise major issues in terms of the transparency and legitimacy of the law-making process. If law firms are able to provide lobbying services without having to register and provide all the required information, we are allowing the creation of a shadow market of public affairs where the legal profession constitutes a non-transparent avenue to law and policy-making.

At the same time, the uncertain boundaries between legal services and lobbying and the related implications raised from a regulatory perspective provide important insights into the changing role of the lawyer in the 21st Century EU and its Member States. The controversy over the registration of law firms in transparency registers for lobbyists points to an underlying tension between, on the one hand, the role of lawyers and the specific features and privileges of the legal profession and, on the other hand, the need to regulate certain activities in order to meet a growing

\footnotetext{
${ }^{3}$ See Adam Chalmers, Trading Information for Access: Informational Lobbying Strategies and Interest Group Access to the European Union, 20 J. EUR. PUB. POL'y 39 (2013).

${ }^{4}$ See Public Policy, Covington, https://www.cov.com/en/practices-and-industries/practices/regulatory-and-public-policy/ public-policy-and-government-affairs (last visited Nov. 21, 2020).

${ }^{5}$ See Political Law, AllEN \& OVERY, http://www.allenovery.com/expertise/practices/public-law/PoliticalLaw/Pages/default. aspx (last visited Nov. 21, 2020).

${ }^{6}$ See Public Policy, Clifford CHANCE, https://www.cliffordchance.com/expertise/services/corporate/public_policy.html (last visited Nov. 21, 2020).

${ }^{7}$ ALBER \& GEIGER, https://albergeiger.com (last visited Nov. 21, 2020).

${ }^{8}$ Id.

${ }^{9}$ Matthias Reimann, The European Advantage in Global Lawyering, 78 RABELS ZEITSCHRIFT FÜr AUSLÄNDISCHES UND INTERNATIONALES PRIVATRECHT 1, 26 (2012).
} 
appetite of modern societies for transparency. As lawyers assume a greater role in policy-making both domestically and transnationally, this tension has the potential to affect the legitimacy of legislative and decision-making processes, and attention should be given to the extent to which regulation at the EU or domestic levels can address it.

Against these general themes, this Article critically examines the phenomenon of law firms involved in regulatory and public affairs in the broader context of lobbying in the EU and the debate around the need for its regulation, in particular the establishment of an EU transparency register for firms and actors involved in lobbying. This Article is organized as follows. In the Section B, I spell out in more detail the key questions. Section C situates the discussion on legal lobbying in the context of the literature on the sociology of the legal profession on the one hand, and regulatory governance on the other hand. In Section D, I introduce the European Union Transparency Register (EUTR) and discuss the exceptions to its application regarding legal advice given by law firms. I show how the EUTR attempts to distinguish between legal services and lobbying by defining two lawyer roles that I call the advocate and the legal expert. Section E elaborates on, and provides some ideas for dealing with, two unresolved issues regarding these roles: the scope of professional secrecy, and the definition of the term legal advice. I conclude by suggesting that an actor identifiable as a lawyer-lobbyist exists, but that a concerted effort at regulatory clarification is necessary to address the implications that legal lobbying raises in terms of transparent and legitimate law-making processes.

\section{B. What Is Legal Lobbying and Why Should We Discuss It?}

Law firms and lawyers are involved in public affairs in many ways. First, lawyers can be retained by companies, private individuals, associations, or non-governmental organizations (NGOs) to lobby on a project-by-project basis. In this capacity, lawyers help scout the terrain and identify policy targets to establish contact. Second, law firms situated in Brussels often specialize in areas such as competition law, intellectual property, and financial policy, which require close proximity to the EU bureaucracy. In this role, lawyers in Brussels-based law firms advocate their clients' views to decision-makers they already know from prior experience in the same policy-making field. An example is offered by Alber \& Geiger, which, according to information on its website, "pressed lawmakers and officials ... to force the European banking regulators to commit to a short investigation and put the emphasis on stability," which "helped to prevent another wave of economic instability." 10 Third, lawyers may also engage in lobbying in their permanent occupations as in-house legal counsel to companies, trade associations or NGOs, where lobbying on behalf of the employer is part and parcel of the job description. ${ }^{11}$ The present focus is on the first two types of law firm lawyer-lobbyists in the context of legal services delivered in the EU.

Should the examples cited in the introduction be defined as lobbying or, more broadly, as involvement in public affairs? With the exception of Alber \& Geiger, the law firm websites do not elaborate on what they mean by the services they offer under a host of labels. Do law firms try to influence legislators and regulators in ways conventionally associated with lobbying, or is this simply advertising puff?

In colloquial parlance, lobbying is generally seen to include someone who is employed by a third party to persuade legislators to pass, or indeed not pass, certain legislation. However, lobbying in fact refers to a wider range of activities that are intended to influence government policy

\footnotetext{
${ }^{10}$ Greece and the European Central Bank, ALBER \& GEIGER, https://albergeiger.com/wins/greece-and-the-european-centralbank/ (last visited Nov. 21, 2020).

${ }^{11}$ Categorization adapted from Gerald L. Gall, The Lawyer as Lobbyist, 15 AlberTA L. Rev. 400, 404-05 (1977). In-house counselling of various kind is not addressed here, as professional roles of, and applicable rules in relation to, lawyers in companies, trade associations, and NGOs differ from lawyers in law firms. For in-house lawyering, see RICHARD MOORHEAD, Steven Vaughan \& Cristina Godinho, In-House Lawyers' Ethics: Institutional Logics, Legal Risk and the TOURNAMENT OF INFLUENCE (2018).
} 
with expertise. ${ }^{12}$ Here, government policy is understood broadly. Lobbyists influence both the formulation and implementation of policy at many levels of government, from legislators to regulatory agencies. Concrete activities of influencing involve monitoring and analyzing policy developments, building reputations with government audiences, contacting decision-makers, preparing and communicating information, organizing events, and participating in and assisting with consultations and hearings. These are the bread and butter of public affairs firms such as FleishmanHillard. Yet these same services are also provided by law firms. For instance, clients of a global law firm like Clifford Chance can buy tailored "electronic monitoring services," and assistance "in preparing responses to consultations."

This gives rise to two observations. First, law firms sell services that can be regarded as lobbying. Public affairs services marketed by law firms, although offered under a rich array of labels, are similar to services offered by public affairs firms. ${ }^{14}$ Second, not only do law firms avoid terms such as "lobbying," "policy advocacy," or "interest representation," but also lawyers who engage in lobbying do not see themselves as lobbyists, but rather as "lawyers in a law firm." ${ }^{15}$ There is apparently a "big difference between practicing law, i.e. advising on legal issues, and representing clients' interests, i.e. lobbying." ${ }^{6}$ What seems to underlie these comments is the belief that activities associated with lobbying are different from traditional lawyering activities, which in a law firm consist primarily of representing clients in courts or advising with respect to contractual or transactional issues. However, lawyering activities have never been limited to these traditional roles. From the inception of the profession, lawyers have also been client advisers, business enablers, and intermediaries. These extra-legal roles, if you will, have not given rise to controversies. ${ }^{17}$ Lawyering activities have also changed in the past. For instance, the emergence of alternative dispute resolution has diversified law firms' portfolios, and mediation and settlement are now a noncontroversial element of a "full-service legal practice." 18 These new roles adopted by lawyers have not run into arguments of incompatibility, for example, "I'm not a mediator, but a lawyer in a law firm." Yet lobbying does not seem to fit this full-service legal practice idea quite so easily.

The sense of incompatibility between the roles of a lawyer and a lobbyist is noteworthy. Unlike business intermediation or civil dispute mediation, ${ }^{19}$ lobbying is a regulated activity in many countries. In the EU, lobbyists are invited to register and annually update and report their lobbying activities in the non-mandatory Transparency Register, set up by the European Parliament and the European Commission. The Transparency Register was formally adopted in 2011, and it currently covers just over 12,000 entries, ranging from consultancy and in-house lobbyists,

\footnotetext{
${ }^{12}$ See Robert A. Dahl, On Democracy 98 (1998); Kenneth Godwin, Scott Ainsworth \& Erik Godwin, Lobbying and Policy-Making: The Public Pursuit of Private Interests 6 (2013).

${ }^{13}$ Clifford Chance, supra note 6.

${ }^{14}$ Although law firms may employ non-lawyers to offer lobbying services, most contacts listed on the above law firms' websites for legal lobbying have legal education and/or training.

${ }^{15}$ This quote is credited to Clifford Chance's Michel Petite, who resigned from the chair of the Commission Ethics Committee after attention was drawn to his role in representing Philip Morris International. Petite resigned but denied any ethical problems. See Nikolaj Nielsen, Tobacco Lawyer Steps Down from EU Ethics Panel, EUOBSERVER (Dec. 23, 2013), https://euobserver.com/institutional/122580.

${ }^{16}$ The phrase is attributed to Angelika Niebler, a MEP who allegedly continued as a lawyer during her parliamentary career. See Martin Banks, EU Parliament Urged to Investigate Possible Conflict of Interest Case Involving MEP, THE PARLIAMENT MAG. (July 29, 2016), https://www.theparliamentmagazine.eu/articles/news/eu-parliament-urged-investigate-possible-conflictinterest-case-involving-mep.

${ }^{17}$ See Lawyers and Vampires: Cultural Histories of Legal Professions (W. Wesley Pue \& David Sugarman eds., 2003); Philip Lewis, Aspects of Professionalism: Constructing the Lawyer-Client Relationship, in THE PARADOX OF Professionalism: LaWyers and the Possibility of Justice 139 (Scott L. Cummings ed., 2011).

${ }^{18}$ George Coombe, Dispute Resolution and the Corporate Law Firm: Toward a Full-Service Legal Practice, 45 ARB. J. 29 (1990).

${ }^{19}$ But see European Code of Conduct for Mediation Providers, EUR. COMM'N FOR THE EFFICIENCY OF JUsT., (Dec. 4, 2018), https://rm.coe.int/cepej-2018-24-en-mediation-development-toolkit-european-code-of-conduc/1680901dc6.
} 
including trade and business associations, to NGOs. ${ }^{20}$ The information registered by the EUTR answers questions such as what interests are being pursued, by whom, and with what budgets. According to Paragraph 7 of the Interinstitutional Agreement (IIA), ${ }^{21}$ the register covers all activities carried out with the objective of directly or indirectly influencing the formulation or implementation of policy and the decision-making processes of the EU institutions, irrespective of where they are undertaken or the channel or medium of communication used. In what follows, the definition included in Paragraph 7 is used as a working definition of lobbying.

Although the EUTR is voluntary, registration has become virtually mandatory, as the Commission only meets with registered lobbyists. ${ }^{22}$ Law firms are the biggest group of actors that have not signed up with the EUTR. Of the four law firms mentioned above, only Covington \& Burling LLP and Alber \& Geiger have registered, and even they do not fully report their activities and clients. Non-registered law firms or those that have registered but only given incomplete information claim that professional secrecy prevents registration or full disclosure. ${ }^{23}$ Other lobbyists, as well as pro-transparency campaigners, dismiss non-registration as a protectionist move, designed to shore up law firm finances. By not registering, law firms potentially win clients who wish to influence decision-makers but do not want to go to public affairs service providers who publicly disclose information about their clients. ${ }^{24}$

Neither of the claims above are plausible. Professional secrecy does not stand in the way of registration, although it may affect how much law firms may disclose and under what conditions. But accusations about protectionism are also off the mark, although the concern about transparency is real. The fact that law firms do not register is not a sign of straightforward business calculations, but rather is indicative of a broader set of questions that have up until now remained unresearched. Is it possible to distinguish lobbying from providing legal services and giving advice? Are the roles of lawyer and lobbyist compatible in such a way that the lawyer-lobbyist exists? If it does, how does it relate to other lawyer roles, or perhaps to the roles of other (non-lawyer) lobbyists? This Article begins answering these questions by showing how the EUTR attempts to distinguish between legal advice and lobbying and regulate lobbying offered by law firms by defining two "ideal-typified" lawyer roles that I call the advocate and the legal expert. ${ }^{25}$ Clarifying how these two roles underpin the EU regulatory regime for lobbyists allows us the ability to pinpoint the two crucial issues that must be solved with respect to legal lobbying.

In the context of a regulatory regime set up by the EUTR, an advocate is someone who practices law and delivers services that can be classified as legal services. This actor type is perceived as bound by professional secrecy and not affected by the EUTR rules. The increasing involvement of law firms and lawyers in the public affairs market has, however, brought uncertainty as to the meaning and scope of the application of professional secrecy. Another legal actor that the EUTR

\footnotetext{
${ }^{20}$ Transparency Register, EUROPA, http://ec.europa.eu/transparencyregister/public/homePage.do.

${ }^{21}$ The Interinstitutional Agreement between the European Parliament (EP) and the European Commission (Commission) sets out the rules and principles on which the EUTR is based. The first IIA was signed in June 2011. The current IIA was adopted on September 19, 2014. See Agreement Between the European Parliament and the European Commission on the Transparency Reg. for Organizations and Self-Employed Individuals Engaged in EU Policy-Making and Policy Implementation, 2014 O.J. (L 277) 1, 11-24 [hereinafter IIA].

${ }^{22}$ Commission Decision 2014/838 of Nov. 25, 2014, On the Publication of Information on Meetings Held Between Directors-General of the Commission and Organizations or Self-Employed Individuals, 2014 O.J. (L 343) 19-21.

${ }^{23}$ See, for example, Alber \& Geiger's EUTR entry. For the terminology, see infra Section E(I).

${ }^{24}$ See, e.g., Nina Katzemich, The Commission Has No Answer to the Opaque Lobbying of Law Firms, EuRAcTIV (Feb. 7, 2018), https://www.euractiv.com/section/politics/opinion/the-commission-has-no-answer-to-the-opaque-lobbying-of-law-firms/.

${ }^{25}$ The word "advocate" is used here to denote a professional who is qualified to practice law-it is not restricted to activities before courts. For the term's historical connotations in different jurisdictions, see Advocate, ENCYC. BRITANNICA, https://www. britannica.com/topic/advocate. Real-life occupations of the advocate are, among others, attorney and solicitor. The "legal expert" refers to a trained lawyer who does not practice law. Both are Weberian ideal types in the sense that they do not directly correspond to actual work titles and are only intended to highlight core features that should be considered when studying legal lobbying.
} 
conceptualizes is a legal expert, who gives advice on law-related matters. Lobbying services offered by this actor type should fall within EUTR rules. But here too the question of uncertain boundaries arises. According to Paragraph 10 of the IIA, the provision of legal advice is excluded from the scope of the EUTR. As legal advice is not defined, the ability to distinguish between lobbying and legal advice in concrete situations poses difficulties. Does, for instance, assistance to clients in preparing responses to consultations, if offered by a lawyer working in a law firm, qualify as giving legal advice or lobbying? Further, and as explained in detail below, the lack of a regulatory definition of legal advice also complicates the application of professional secrecy.

Before considering the literature on legal lobbying, some further working definitions are required. The lawyer-lobbyist is a lawyer who has legal education and/or training and who sells his or her expert knowledge to help his or her clients manage relationships with legislators or regulators and to help them achieve regulatory change or clarification. As a term, legal lobbying refers to activities undertaken by a lawyer that are intended to influence legislators and regulators. The definition that I have adopted here corresponds with the general definition of lobbying put forward by the EU. ${ }^{26}$ Some examples of legal lobbying include drafting a response to a public consultation, identifying and communicating to decision-makers potential problems with respect to certain legal provisions, or setting up and/or accompanying a client to a meeting to discuss policy-sector developments.

\section{Legal Lobbying as an Object of Study}

Legal lobbying is a multifaceted phenomenon and can be examined from a variety of perspectives. Below, two alternative perspectives are discussed.

First, legal lobbying can be approached as part of a larger discussion on the sociology of professions, and specifically how the legal profession has changed over the decades. Many of the insights in this literature, although not explicitly addressing legal lobbying, explain the tendency of law firms to enter the public affairs market. ${ }^{27}$ One such insight is that law firms provide lobbying services to corporations, individuals, trade associations, and NGOs simply because there is less demand for traditional lawyering. Richard Susskind argues that future lawyers would need to be reborn as legal hybrids and rebrand themselves as "strategists, management consultants, business advisers, market experts, deal brokers, organizational psychologists, and the rest." ${ }^{28}$ Indeed, during the last two decades, in order to remain profitable, "large law firms have become increasingly corporatized with the inclusion of human resources, marketing, risk analysis and compliance counsel, finance, and technology departments." ${ }^{29}$ Besides the dwindling demand for more traditional services, Brussels-based law firms especially have reorganized their business models and service portfolios to respond to transatlantic business provocation.

Second, as early as the 1960s, the arrival of American firms on the highly domestic European legal market created sudden competitive pressure and led to mergers and a radical rethinking of the whole legal services sector in Europe to involve new types of services, including lobbying.

\footnotetext{
${ }^{26}$ IIA at para. 7.

${ }^{27}$ For a sociological perspective on the legal profession, see Richard Abel \& Philip Lewis' three-volume edition of LAWYERS IN SOCIETY (1988-1989). See also Richard Abel, Comparative Sociology of Legal Professions: An Exploratory Essay, 10 LAW AND Soc. Inquiry 5 (1985); Terence Halliday, Beyond Monopoly: LaWyers, State Crises, and Professional Empowerment (1987); The Sociology of the Professions: Lawyers, Doctors and Others (Robert Dingwall \& Philip Lewis eds., 2014). In the EU context, see Professional Competition and Professional Power-Lawyers, Accountants and the Social Construction of Markets (Yves Dezalay \& David Sugarman eds., 1995); Christopher Whelan \& Doreen McBarnet, Lawyers in the Market: Delivering Legal Services in Europe, 49 J. L. \& Soc'Y 49 (1992); antoine Vauchez, Brokering Europe: Euro-Lawyers and the Making of Transnational Polity (2015).

${ }^{28}$ Richard Susskind, TOMORROW's LAWYers: An InTroduction to Your Future 113 (2013).

${ }^{29}$ John Flood, The Re-Landscaping of the Legal Profession: Large Law Firms and Professional Re-Regulation, 59 CURRENT SocIO. 507, 512 (2011).
} 
The EU also actively contributed to the emergence of new forms of lawyering by hiring, for instance, the American law firm Cleary Gottlieb to manage fledgling transatlantic relations and to serve as a political agent of the EU in the United States. American law firms had a very different approach to lawyering, offering services that were "beyond a strictly legal scope (legal advice, public relations, and lobbying, etc.)." 30 The pressure created by U.S. law firms was felt first and most acutely in Brussels, but eventually what John Flood calls U.S. "megalaw" also arrived in the Member States. ${ }^{31}$ Despite the revamping of legal services that subsequently occurred both in Brussels as well as in Member State capitals, American law firms have continued to pose a threat to their European rivals. Commenting on London law firms, Yves Dezalay notes:

The fragility of the large City law firms explains in part their ambivalence as regards lobbying. In spite of recent efforts to recruit leading former members of European institutions, in order to profit from their wide networks of relations, they are still far from having accumulated the kind of political capital that enables the Washington law firms to serve as operational bases for elder statesmen, marketing high level lobbying as power-brokers. ${ }^{32}$

Instead, Europeans have habitually offered what is called "legislative vigil," something undertaken by young inexperienced professionals. ${ }^{33}$

A third reason may also be suggested for the entry of Brussels law firms into public affairs. Particularly in the early stages of EU integration, lawyers monopolized key governance positions. Statistical data collected by sociologists of the legal profession shows that "lawyers and, more generally, legally trained elites, occupy prominent positions in the various economic, bureaucratic, and political institutions and organizations that emerged through European integration." 34 From the perspective of a client and taking into account the context in which many decisionmakers have been and still are lawyers, hiring lawyers to lobby seems wise, and the law firms in Brussels have, so the argument goes, simply responded to client demand.

The sociology of professions literature, although abundant, has focused on institutional changes in the legal profession and offers less research specifically interested in lawyers as actors and their regulation. Another possible perspective from which to approach legal lobbying and its regulation is good governance and, more specifically, the transparency and legitimacy of the decision-making process. From this point of view, lawyers' reluctance to register as lobbyists and provide information appears like an intentional avoidance of lobbying regulation rules, which ultimately violates the public's right to know how the decisions that affect them have been made. ${ }^{35}$ Lobbying regulations pursue transparency through the so-called legislative footprint. It is a document that can be annexed to a legislative measure detailing the time, relevant people, and subject matter of a legislator's contact with a lobbyist. Lobbying

\footnotetext{
${ }^{30}$ VAUCHEZ, supra note 27, at 65.

${ }^{31}$ John Flood, Megalaw in the U.K.: Professionalism or Corporatism? A Preliminary Report, 64 IND. L.J. 569 (1989).

${ }^{32}$ Yves Dezalay, Opportunities and Limits of a Weak Field: Lawyers and the Genesis of a Field of European Economic Power, in Lawyering Europe: European Law as a Transnational Legal Field 272 (Antoine Vauchez \& Bruno de Witte eds., 2013).

${ }^{33}$ Daniel Kelemen, Eurolegalism and the European Legal Field, in LAWYERING EUROPE, supra note 32, at 247.

${ }^{34}$ Antonin Cohen \& Antoine Vauchez, Introduction: Law, Lawyers, and Transnational Politics in the Production of Europe, 32 LAW \& SOC. INQUIRY 78 (2007).

${ }^{35}$ See Venice Comm'n, Report on the Role of Extra-Institutional Actors in the Democratic System (Lobbying) para. 62 (Mar. 22, 2013), https://www.venice.coe.int/webforms/documents/default.aspx?pdffile=CDL-AD(2013)011-e (arguing that " $[\mathrm{i}] \mathrm{n}$ the context of lobbying, transparency means that information is available to the public not only about government activity, its motives and objective, but also but also about private interests attempting to influence the State when public policy is formulated. A political system is transparent if such information is available to those who will be affected by governmental law-making, decisions and enforcement ...").
} 
registers combine this information for a large number of measures. ${ }^{36}$ If law firms do not register or disclose information on whose behalf they have contacted decision-makers, the legislative footprint, and hence also the transparency of public decision-making, is incomplete.

Lawyer-lobbyists are a special breed among their lobbying peers, and to date they-and more broadly, the involvement of law firms in public affairs-have not attracted scholarly attention in the EU. The discussion about transparency concerns raised by lawyer-lobbyists has primarily been conducted by pro-transparency NGOs that are worried about the success with which lawyers attract clients who wish to influence policy-makers behind the scenes and who would rather not associate themselves with the unpleasantness of lobbying. ${ }^{37}$ While such debate is welcome, it is primarily a policy-driven discussion conducted by transparency campaigners and marketplace rivals. What is missing is an academic understanding of the phenomenon. A tendency to overlook lawyers as potential lobbyists is not an omission made only at the EU level, but also in some Member States. ${ }^{38}$ In countries such as Portugal and Estonia, members of the legal profession are the primary providers of lobbying services, and yet they remain unregulated in that role, which is also the case in other jurisdictions. In the United Kingdom, the Transparency of Lobbying, Non-Party Campaigning and Trade Union Administration Act of 2014 establishes a register of persons carrying on the business of lobbying but excludes lawyers from its scope. ${ }^{39}$ The current focus is on the EU level, so the in-depth analysis of different Member State developments must be left for future research. In the US, law firms offering lobbying services are very common. According to the Center for Responsive Politics, an American transparency NGO, eight of the twenty top lobbying firms are law firms, including the biggest two. ${ }^{40}$ This Article makes occasional references to U.S. literature and case law, but a larger comparative analysis of U.S. practice (federal and state) must be left for another occasion.

The two perspectives mentioned above, that is, the legal profession literature and the good governance approach, see lawyer-lobbyists in similar ways. For both sociologists of the legal profession and those interested in regulating lobbyists, lawyers engaged in lobbying are focused on safeguarding their occupational status. There is arguably "considerable resistance by the legal profession in the EU to become enmeshed into the institutionalization of public affairs," which leads the legal profession to "safeguard its occupational status and privileges" and to "dissociate itself from regulatory debates related to governance and interest representation." ${ }^{41}$ While there is certainly some truth to this claim, professional self-preservation is only part of the picture. Focusing solely on how legal professionals fight for their turf in an increasingly competitive global legal market helps explain why the legal profession has entered the public affairs market, but not why it avoids labelling their work as lobbying and registering in the EUTR. Prior to that discussion, I briefly introduce the regulatory debates from which the legal profession aims to dissociate itself.

\footnotetext{
${ }^{36}$ See Eur. Parliament, Briefing for the PETI Committee: Transparency, Integrity and Accountability in the EU Institutions (Mar. 2019), https://www.europarl.europa.eu/RegData/etudes/BRIE/2019/608873/IPOL_BRI(2019) 608873_EN.pdf.

${ }^{37}$ Transparency Int'l, Lobbying in Europe: Hidden Influence, Privileged Access (2015); Alter-EU, Lobbying LaW FiRMS-UNFINISHED Business (2016).

${ }^{38}$ Staff Working Paper: Report on the Consultation of the European Network of Ombudsmen on Public Officials' Interaction with Interest Representatives, EuR. OMBUdSMAN (May 25, 2016), https://www.ombudsman.europa.eu/fi/letter/en/67521.

${ }^{39}$ TransPaRENCY INT'L, supra note 37 , at 15.

${ }^{40}$ See Top Lobbying Firms, CTR. FOR RESPONSIVE POL., https://www.opensecrets.org/federal-lobbying/top-lobbying-firms? cycle $=2019$ (last visited Nov. 21, 2020). For U.S. literature, see, for example, Robert L. Nelson, John P. Heinz, Edward O. Laumann \& Robert Salisbury, Lawyers and the Structure of Influence in Washington, 22 L. \& Soc'Y REV. 237 (1988).

${ }^{41}$ Christian Lahusen, Law and Lawyers in the Brussels World of Commercial Consultants, in LAWYERING EUROPE, supra note 32, at 192. For spheres of competence between lawyers and other experts, see Mark J. Osiel, Lawyers as Monopolists, Aristocrats, and Entrepreneurs, 103 HARv. L. Rev. 2009 (1990) (book review); Yves Dezalay, Turf Battles and Tribal Wars, 54 MOD. L. REV. 792 (1991).
} 


\section{Regulation of Legal Lobbying in the EU \\ 1. The EUTR as a Regulatory Framework}

If a law firm engages in activities defined as lobbying in Paragraph 7 of the EU IIA ("activities intended to influence policy-making"), it should register in the EUTR and provide information about such activities. The requested information covers identifying information such as contact details, the number of people involved in lobbying, as well as information regarding the main EU legislative and policy initiatives followed by the registrant. Moreover, the law firm needs to provide information about its turnover attributable to lobbying activities and about its clients, including the relative weight of each client in accordance with a defined grid. Organizations registered or operating in more than one country, such as global law firms, should register only once. Registering generally falls to the branch or office dealing with EU affairs, usually the Belgiumbased office. ${ }^{42}$ By registering, lobbyists also commit to respect the Code of Conduct attached to the EUTR. ${ }^{43}$

Paragraphs 10-12 limit the scope of the EUTR by excluding certain activities. The most important limitation concerns "the provision of legal and other professional advice" in Paragraph $10 .{ }^{44} \mathrm{It}$ sets out five situations where activities relating to legal advice fall outside the EUTR. The first concerns "advisory work and contacts with public bodies in order to better inform clients about a general legal situation or about their specific legal position, or to advise them whether a particular legal or administrative step is appropriate or admissible under the existing legal and regulatory environment." The second situation when the EUTR does not apply is when a client is advised on how to comply with the law. The third exemption concerns the provision of analyses prepared for clients on the potential impact of any legislative or regulatory changes with regard to their legal position or field of activity. The fourth and fifth limitations concern advice given in the context of dispute resolution processes, and advice that relates to the exercise of the fundamental right of a client to a fair trial, including the right of defense in administrative proceedings. ${ }^{45}$ Finally, it is further specified that "if a company and its advisers are involved as a party in a specific legal or administrative case or procedure, any activity relating directly thereto which does not seek as such to change the existing legal framework is not covered by the register." ${ }^{\prime 46}$

After defining the exempt activities, Paragraph 10(3) goes on to define two situations in which activities concerning the provision of legal advice are included within the scope of the EUTR. First, legal advice falls within the EUTR when it consists of "the provision of support, via representation or mediation, or of advocacy material, including argumentation and drafting." Second, legal advice also falls within the scope of the EUTR when it can be understood as "the provision of tactical or strategic advice, including the raising of issues the scope of which and the timing of communication of which are intended to influence the EU institutions, their Members and their assistants or their officials or other staff."

The principle is therefore clear. Any law firm engaging in activities covered by the EUTR on behalf of clients - or on their own behalf-should register and reveal their clients and the respective revenue earned. Nevertheless, Paragraph 10 is written in an unnecessarily difficult fashion, and the precise scope of obligations covered by this provision is unclear. Litigation and adversarial proceedings are clearly excluded, whereas the distinction between activities that relate to exempt legal advice on the one hand and non-exempt legal advice on the other hand is ambiguous.

\footnotetext{
${ }^{42}$ See Guidelines: How to Achieve a Good Registration \& Avoid Common Mistakes, EUROPA TransParEnCY REG., https:// ec.europa.eu/transparencyregister/public/staticPage/displayStaticPage.do?locale=en\&reference=GUIDELINES.

${ }^{43} \mathrm{See}$ Code of Conduct, EUROPA TRANSPARENCY REG., http://ec.europa.eu/transparencyregister/public/staticPage/ displayStaticPage.do?locale=en\&reference=CODE_OF_CONDUCT (last visited Nov. 21, 2020).

${ }^{44}$ Other limitations concern activities of the social partners as participants in the social dialogue (paragraph 11) or activities in response to direct and individual requests from EU institutions or Members of the EP (paragraph 12).

${ }^{45}$ IIA at para. $10(1)$.

${ }^{46} I d$. at para. $10(2)$.
} 
For instance, the relationship between "advisory work and contacts with public bodies in order to better inform clients about a general legal situation" (exempt) and "the provision of support or advocacy material" (non-exempt) confuses rather than clarifies. Furthermore, the limitation concerning analyses prepared for clients on the potential impact of legislative or regulatory changes is problematic because the preparation of such analyses constitutes a central pillar in the work of non-lawyer-lobbyists. Why should lawyers be able to provide these analyses as legal advice and not register as lobbyists if the non-lawyer professionals that prepare the same analyses need to register? Although the Joint Secretariat of the EUTR has published implementing guidelines, ${ }^{47}$ these have neither clarified the definition of legal advice nor provided any concrete examples of situations where the murky distinction between exempt legal advice and non-exempt legal advice may cause problems.

The legal advice exception also exists in other jurisdictions. In the U.S., for instance, Section 3(8)(B)(xii) of the 1995 Lobbying Disclosure Act (LDA) stipulates that "lobbying contact" does not include a communication that is made to an official in an agency with regard to

(I) a judicial proceeding or a criminal or civil law enforcement inquiry, investigation, or proceeding; or (II) a filing or proceeding that the Government is specifically required by statute or regulation to maintain or conduct on a confidential basis, if that agency is charged with responsibility for such proceeding, inquiry, investigation, or filing $[\ldots]^{48}$

The legal advice exception in the LDA is narrower than the one in the EUTR. The former excludes from its scope only communications that occur with respect to formal legal proceedings. In the LDA, the main principle is registration, and non-disclosure on account of the legal advice exception is a departure from the main principle. The straightforwardness with which the LDA treats legal lobbying has most likely contributed to how few controversies there have been with regard to the regulation of lawyer-lobbyists in the U.S. ${ }^{49}$ Law firms are seen as one type of lobbying firm together with political consultancy firms, think tanks, and public relations agencies, all of which are subject to regulation..$^{50}$ As discussed below, the American Bar Association has positively contributed to regulatory clarity by revising its Model Rules to recognize the lobbying services offered by lawyers and law firms and to enable lawyer-lobbyists to fulfill their LDA duties. ${ }^{51}$

In 2013, the coverage of the EUTR was estimated to be sixty-five percent for business interests and seventy percent for NGOs. ${ }^{52}$ Law firms constitute the only group that systematically avoids registration. A search on the register reveals that in November 2020, there were eighty-seven entries by law firms, less than one percent of the total number of registrations. Comparing the list of registered law firms with a list of sixty major Brussels-based law firms specializing in international and/or European law and policy reveals that only a quarter, thirteen, have entered the register. ${ }^{53}$ Most law firms in the EUTR cover small or medium-sized offices operating in one or

\footnotetext{
${ }^{47}$ See EUROPA TRANSPARENCY REG., supra note 42.

${ }^{48} 2$ U.S.C. $\$ 1601$ (2000).

${ }^{49}$ The only exception is Pennsylvania, where lobbying disclosure rules were invalidated on the grounds that the statute unconstitutionally interfered with the legal profession's activities. See Gmerek v. State Ethics Comm., 751 A.2d 1241 (Pa. Commw. Ct. 2000). The Pennsylvania legislature enacted a new lobbying statute, 65 PA. STAT. AND CONS. STAT. ANN. $\$ \$$ 13A01-13A11 (West 2008), after the State Supreme Court authorized the regulation of lawyer lobbyists. See Gmerek v. State Ethics Comm., 807 A.2d 812 (Pa. 2002). Recent controversies in the U.S. have concerned violations by lawyers of the Foreign Agents Registration Act (FARA). See, e.g., United States v. Craig, 401 F. Supp. 3d 49 (D.D.C. 2019) (a high-profile case involving Gregory Craig).

${ }^{50}$ Vincent R. Johnson, Regulating Lobbyists: Law, Ethics, and Public Policy, 16 CORnEll J.L. \& PUB. POL'Y 1 (2006).

${ }^{51}$ See Thomas Ross, Ethics Law and the Lawyer/Lobbyist, in The Lobbying Manual: A Complete Guide To Federal Lobbying Law and Practice 689, 691-92 (William Luneburg, Thomas Susman \& Rebecca H. Gordon eds., 2009).

${ }^{52}$ Justin Greenwood \& Joanna Dreger, The Transparency Register: A European Vanguard of Strong Lobby Regulation, 2 INT. Groups \& ADVOC. 147 (2013).

${ }^{53}$ Law Firms, BRUSSELS LEGAL, https://www.brusselslegal.com/article/display/2984/Law_Firms (last visited Nov. 21, 2020).
} 
two Member States. Most of the registered firms declare relatively little lobbying related expenditure, with the exception of Covington \& Burling LLP, whose last estimated lobbying costs in 2018 were between $€ 1,000,000$ and $€ 1,249,999$.

The Council of Bars and Law Societies of Europe (CCBE) has been commendably active in relation to the EUTR. The CCBE has a committee devoted to the EUTR that works towards "supporting transparency in the decision-making of the EU institutions as a prerequisite for legitimacy, by stressing the need for the highest level of transparency without breaching existing deontological rules, for example rules on confidentiality recognized by the European Court of Justice." 54 In response to the public consultation on the reform of the EUTR in 2012, the CCBE expressed concerns about the exact meaning of "indirect" influence, referring particularly to cases where a lawyer is contracted to provide legal advice to a client on future legislation and to contact EU institutions. The CCBE pointed out that such a situation should not be seen as covered by the EUTR rules. Further, the CCBE noted that some of the activities covered by the EUTR, such as the preparation of information material and papers, are at odds with professional secrecy. ${ }^{55}$ When the EUTR was revised in 2013, a working group took on board the suggestions put forward by the CCBE. For instance, the revised IIA exempted the preparation of legal analyses of future regulations from regulation. ${ }^{56}$

The European Commission published the proposal for the new EUTR in $2016 .{ }^{57}$ In this version, the legal advice exception focuses on formal proceedings that are capable of altering the rights or interests of parties, implying that fewer activities would be exempted. In connection with the new proposal, lawyers have joined forces with pro-transparency campaigners. In a joint letter addressed to EU institutions, the CCBE, together with other signatories, argued that it will lead by example and file complete, accurate, meaningful, and up-to-date information, but regretted that its "commitments to transparency and accountability are not yet shared by all." 58 It is questionable, however, whether the CCBE is indeed leading by example with respect to its ostensible commitment to transparency. The CCBE may well support the view that even law firms influencing EU decision-making must sign-up with the EUTR, but, as will be explored shortly, it interprets deontological rules in ways that compromise the legal profession's commitment to transparency and accountability with respect to lobbying.

\section{The EUTR's Two Lawyer Roles}

As seen above, the EUTR's provisions differentiate between exempt legal services and non-exempt lobbying services offered by lawyers. In this section, I demonstrate how, in so doing, the EUTR makes a distinction between two lawyer roles, namely that of a legal expert and that of an advocate, even though in practice the lawyer-lobbyist sways between these roles.

The first lawyer role that can be inferred from the EUTR is that of a legal expert, someone who engages in the "provision of support in argumentation and drafting" as well as the "provision of

\footnotetext{
${ }^{54}$ European Transparency Register Working Group, COUNCIL OF BARS AND L. SOCIETIES OF EuR., https://www.ccbe.eu/ actions/committees-working-groups/?idC=547\&Committee=European\%20Transparency\%20Register.

${ }^{55}$ Council of Bars and L. Societies of Eur., General Response to the European Commission Consultation ON THE Transparency Register, (Sept. 7, 2012), http:/www.ccbe.eu/fileadmin/speciality_distribution/public/documents/ EUROPEAN_TRANSPARENCY_REGISTER/ETR_Position_papers/EN_ETR_20120907_CCBE_General_response_to_the_ consultation_on_the_Transparency_Register.pdf.

${ }^{56}$ IIA at para. 10(1).

${ }^{57}$ Commission Proposal for an Interinstitutional Agreement on a Mandatory Transparency Register, at art. 3(2)a, COM (2016) 627 final (Sept. 28, 2016). After years of interinstitutional wrangling and delays, the negotiations were restarted in Spring 2020.

${ }^{58}$ Joint Letter: Lobbyists for Transparent Lobbying, http://transparency.eu/wp-content/uploads/2017/01/Joint-letterLobbyists-for-transparent-lobbying-1.pdf (last visited Nov. 21, 2020). The CCBE itself has signed up to the EUTR as a professional association.
} 
tactical or strategic advice." ${ }^{\text {99 }}$ A standard conception of a legal expert is a legally trained government official, such as legal advisors in ministries and regulatory agencies, or appointed experts such as legal academics who give expert evidence to governments and parliaments on policy matters that include law-related problems. Therefore, a typical example of the kind of legal expertise that these actors provide would indeed be support in argumentation and drafting when preparing new legislation. Legal experts are also often called upon to consider matters of principle; for example, human rights and financial stability. ${ }^{60} \mathrm{~A}$ legal expert should identify as many legal risks and uncertainties as possible and provide a balanced, detailed, and strategically tailored opinion on the policy-making issues at hand.

This expert lawyer role connects to the way in which the EUTR more generally perceives lobbyists. The Code of Conduct attached to the EUTR stipulates that the information that lobbyists provide should be "complete, up-to-date and not misleading." ${ }^{61}$ Lobbyists are therefore required to provide qualified information that decision-makers can trust, in other words, to bring expertise to the policy-makers' table. Does the expertise that lawyer lobbyists feed into the decision-making process differ from the expertise offered by non-lawyer lobbyists? There is no clear way to define or describe legal expertise, but often the expertise that members of the legal profession possess is characterized in instrumental, technical, and technocratic terms. ${ }^{62}$ As Gall summarizes:

Members of the legal profession ... have an appreciation of the intricacies of our political and decision-making machinery. As a result of formal legal education as well as the practice of law, lawyers generally have the ability to define precisely the material issues in a given concern and to provide the organizational machinery to articulate that concern. ${ }^{63}$

The legal profession is perceived to be concerned with technical issues of legal doctrine, such as the applicability of laws or precedents in particular contexts, or the interpretation or enforceability of contracts. ${ }^{64}$ But as the above quote suggests, lawyers also have an appreciation of the organizational machinery, a useful skill which opens doors in complex policy environments such as the EU. The increasing importance and complexity of secondary decision-making-delegated and implementing acts - only emphasizes the demand for legal experts who can competently navigate the intricate EU rule-making processes. ${ }^{65}$

The other lawyer role, that of the advocate, can also be inferred directly from the EUTR. As explained above, the EUTR provisions describe and exempt from regulation a range of activities that are typically associated with the role of an advocate, such as advice in relation to "whether a particular legal or administrative step is appropriate or admissible under the existing legal and regulatory environment," or activities relating to "the exercise of the fundamental right of a client to a fair trial." 66 Through this broadly framed exception, the EUTR framework constructs the role of an advocate, that is, a practicing lawyer advising clients on legal issues or conducting litigation.

Advocacy is "the most important part of what most lawyers do," and the role of the advocate is the "dominant image of lawyers as a group." ${ }^{7}$ Somewhat paradoxically, the advocate role overlaps

\footnotetext{
${ }^{59}$ IIA at para. $10(3)$.

${ }^{60}$ Lewis, supra note 17.

${ }^{61}$ EUROPA TRANSPARENCY REG., supra note 43 (emphasis added).

${ }^{62} \mathrm{An}$ emphasis on the specificity and technicity of the law is sometimes seen as a counterreaction of the legal profession to the threat of other professions entering into the legal field. See Harm Schepel \& Ramses Wesseling, The Legal Community: Judges, Lawyers, Officials and Clerks in the Writing of Europe, 3 EuR. L.J. 168 (1997).

${ }^{63}$ Gall, supra note 11 , at 402 (emphasis added).

${ }^{64}$ Lahusen, supra note 41, at 178.

${ }^{65}$ Daniel Gueguen, Bad News for EU Decision-Making: Comitology No Longer Exists, EuRAcTIV (Apr. 19, 2013), https:// www.euractiv.com/section/public-affairs/opinion/bad-news-for-eu-decision-making-comitology-no-longer-exists/.

${ }^{66}$ IIA at para. 10.

${ }^{67}$ Anthony Kronman, The Lost Lawyer: Failing Ideals of the Legal Profession 147 (1993).
} 
with that of the lobbyist. The advocate, just like the lobbyist, "speaks to others on his client's behalf and does not—cannot-show any ... ambivalence or uncertainty about the client's position." 68 In rare instances where legal lobbying is discussed in the literature, the phenomenon is compared to advocacy and lawyer-lobbyists are compared to advocates. To some, lobbying is "a form of advocacy .... An understanding of legal doctrine is often important in lobbying as are familiarity with the formal and informal procedures of government decision making." 69

And so, for the first lawyer role, the EUTR provisions envisage a technocratic legal expert who not only argues and drafts, but who can also strategically deploy the organizational machinery to convey the client's message to the policy-maker. The legal expert type is regulated under the EUTR. As for the second role, the EUTR conceives a practicing lawyer who engages in strictly legal activities; this advocate type is not regulated under the EUTR.

In theory, it is possible to keep these roles distinct and subject them to different regulatory requirements - as the EUTR does-but in practice they are inevitably intertwined. As an actor, the lawyer-lobbyist sways between the two roles. Consider how Alber \& Geiger defines its own role as providing legal services for an unnamed Greek bank. On its website, it describes how it occupied itself with identifying and educating decision-makers about legal and public interest implications that the scrutiny - which the law firm's successful lobbying helped avoid-would have had for "the bank itself, the Greek banking sector in general and ultimately on EU taxpayers' money."70 This activity clearly falls in the category of non-exempt tactical and strategic advice. In this respect, when providing advice and contacting decision-makers on behalf of its client bank, Alber \& Geiger assumes the role of a legal expert and becomes subject to the EUTR rules. But the firm's attorneys provide legal expertise in the capacity of an advocate, which, through its connection to professional secrecy, precludes the application of lobbying rules. And so even though Alber \& Geiger is one of the rare registered law firms, none of its listed clients on the EUTR is a Greek bank. The law firm provides professional secrecy as a general explanation for incomplete listings of its clients and revenues. ${ }^{71}$ This example shows why legal lobbying is an issue from the perspective of transparency and why the EUTR is not succeeding. Had the law firm not blogged about its successful lobbying campaign for the unnamed Greek bank, there would have been no way of obtaining this information.

This oscillation between two roles is further underscored by the fact that the lawyer-lobbyist is often hired to offer both advocacy as well as expert lobbying. In the context of EU competition law, law firms "assisting a company on a specific case ... would normally tend to offer also the complementary institutional monitoring services" in order to ensure that "the narrative" is consistent and in line with the overall legal strategy. ${ }^{72}$ If the case file entails some legal elements, it is probable that the client finds it easier to hire a lawyer or a team of lawyers who can handle both, rather than hiring two sets of professionals from a law firm and a public relations firm.

In conclusion, the lawyer-lobbyists undertake tasks that require them to act like legal experts. But because they do so while remaining part of the legal profession as an advocate, their lobbying activities, delivered either alone or in conjunction with more conventional legal services, allegedly fall outside lobbying rules and remain hidden. As noted above, pro-transparency advocates and the lobbying industry tend to see this as a calculated business strategy. But non-registration may also result from an uncertainty created by the dual role of a lawyer-lobbyist. First, the legal expert

\footnotetext{
${ }^{68} \mathrm{Id}$. at 146.

${ }^{69}$ Quintin Johnstone \& Dan Hopson, Lawyers and Their Work: An Analysis of the Legal Profession in the UNITED STATES AND ENGLAND (1967) (quoted in Gall, supra note 11, at 402).

${ }^{70}$ Alber \& GEIGER, supra note 10.

${ }^{71}$ The registration entry of Alber \& Geiger comes with the caveat that "only clients and revenues which are not subject to lawyers' legal privilege have been listed above.” Id. at https:/ec.europa.eu/transparencyregister/public/consultation/ displaylobbyist.do?id=67820416722-09.

${ }^{72}$ Cristina Mariani \& Simone Pieri, Lobbying Activities and EU Competition Law: What Can Be Done and How, 5 J. EuR. Comp. L. \& Prac. 1, 7 (2014).
} 
role of the lawyer-lobbyist raises the boundary problem: where does legal advice end and lobbying begin? Second, another dilemma emerges in relation to the advocate role. Law firms may think that the advice offered by their attorneys is non-exempt legal advice, but they do not register because they think that this would breach certain deontological rules of the profession. I address both situations in detail below, starting with professional secrecy.

\section{E. Legal Lobbying from the Perspective of Deontological Rules}

\section{Legal Lobbying and Professional Secrecy}

Professional secrecy is at the core of the activities of the legal profession..$^{73}$ Despite its centrality, no generally accepted definition exists. The concept differs from one Member State to another, and between common law and civil law countries. The former use the terms "legal professional privilege" (U.K.) and "attorney-client privilege" (U.S.), while "professional secrecy" is more common in the latter. ${ }^{74}$ There are also some differences in how the concept is precisely formulated and understood across jurisdictions. For instance, in civil law countries, the notion of professional secrecy is broad and covers considerations of confidentiality more generally. Consequently, the discussion of legal lobbying in civil law countries is defined by reference to professional secrecy. In common law countries, attorney-client privilege and the duty of confidentiality are two distinct concepts. The question of whether law firms can register and disclose is determined in common law countries by reference to the duty of confidentiality. The privilege is a rule of evidence that precludes the disclosure of confidential communications in court. ${ }^{75}$

The geographical scope of the present analysis is limited to professional rules applicable in Belgium, and this contribution uses the civil law term of professional secrecy and understands it broadly to cover confidentiality considerations. This focus is justified because lawyers in Belgium (where the key EU institutions are) are most affected by the EUTR, and the CCBE has, as explained below, asked the Belgian bar associations to define their position in relation to the EUTR. ${ }^{76}$

Despite national variations, the core idea of professional secrecy remains the same: to protect communication in a situation where the lawyer is told things which the client would not tell others. The lawyer must "maintain confidentiality of information disclosed by a client in the context of the attorney-client relationship and the right of the client to consider any advice given to him confidential." 77 It is first and foremost the right of the client, not that of the lawyer; professional secrecy can only be waived by the client. Most Member States, including Belgium, accept the client's right to waive the rules of confidentiality. ${ }^{78}$

\footnotetext{
${ }^{73}$ Dirk Van Gerven, Professional Secrecy in Europe, in Professional Secrecy of Lawyers in Europe 2 (2013). See also Council of Bars and L. Societies of Eur., Charter of Core Principles of the European legal Profession and Code OF CONDUCt For European LAWYers (2013), https://www.ccbe.eu/NTCdocument/EN_CCBE_CoCpdf1_1382973057.pdf.

${ }^{74}$ Paul Lefebvre, David Rosenberg, Matthew Zwick \& Chloé Vialard, Legal Professional Privilege: Comparing Different Approaches Within the United States and the European Union, 79 Def. Couns. J. 49, 55 (2012). Professional secrecy was also recognized by the European Court of Justice in Case 155/79, AM \& S Europe Ltd. v. Comm'n, 2008 E.C.R. 1975, at paras. 21, 23. The Court held that the confidentiality of written communications between lawyers and clients is protected. However, this protection is subject to two cumulative conditions: First, the exchange with the lawyer must be connected to the "client's right of defense"; second, the exchange must emanate from "independent lawyers." The second condition was unsuccessfully disputed in a case concerning in-house lawyers. See Case C-550/07 P, Akzo Nobel Chems. \& Akcros Chems. v. Comm'n, 2010 E.C.R. I-8301. See also Julia Holtz, Legal Professional Privilege in Europe: A Missed Policy Opportunity, 4 J. Eur. ComP. L. \& PRAC. 402 (2013).

${ }^{75}$ Ross, supra note 51 , at 694-97.

${ }^{76}$ Van Gerven, supra note 73, at 22.

${ }^{77} I d$. at 2 . The rationale for professional secrecy lies in the idea of a circle of truth: It is important that the client speaks the truth, thus enabling the lawyer to give accurate advice. See Joan Loughrey, Accountability and the Regulation of the Large Law Firm Lawyer, 77 Mod. L. REv. 743 (2014).

${ }^{78}$ Van Gerven, supra note 73 , at 15.
} 
Professional secrecy covers information provided to the lawyer for the purpose of seeking legal advice; more specifically, "any information a lawyer receives or obtains in the context of assisting a client in relation to legal proceedings or any conflict in general or to determine the rights and obligations of the client." but to an "assessment of the client's legal position." ${ }^{80}$ Furthermore, professional secrecy covers the lawyer's duty to "defend a client's interests in law." 81 If a lawyer serves as, for example, a company director, the information he or she obtains in this role is not protected. ${ }^{82}$ The role in which a lawyer serves a client is, however, not decisive in all cases. Dirk van Gerven, Emeritus President of the Brussels Bar, holds that professional secrecy is limited to information obtained in the practice of law and that any information gleaned outside the exercise of the legal profession-for example, when the lawyer acts as a company director, a trustee in bankruptcy, or a lobbyist—is not usually protected. But he specifies that:

[W]hen a lawyer serves as a director, liquidator or court-appointed trustee, the lawyer is not acting on behalf of or providing assistance to a client. Information obtained from lobbying activities is, of course, only privileged to the extent such activities are intended to define or enhance the legal position of a client. Indeed, lobbying on behalf of a client could also constitute the provision of assistance to the client in defining a legal position or avoiding litigation. $^{83}$

In Belgium, then, lobbying on behalf of a client may constitute the provision of legal advice and be protected by professional secrecy.

What then is the relationship of professional secrecy to the EUTR? The occasional visitor to the EUTR website does not find any link to national bar associations, and professional secrecy is neither defined nor explained. A closer look may reveal that some registered law firms have, after enumerating some of their clients, added references to "lawyers' legal privilege" or caveats according to which the law firm and its lawyers adhere to relevant bar rules. ${ }^{84}$ There is no further explanation on the site as to the exact meaning of these caveats and qualifications. In order to offer much-needed clarity, the CCBE adopted a policy position on the matter. As many of the lawyers working in Brussels are members of the Belgian bar associations, its position was defined jointly with the Brussels Bar Association, the Society of Dutch-Speaking Bar Associations (Orde van Vlaamse Balies), and the Society of French and German-Speaking Bar Associations (Ordre des barreaux francophones et germanophone). According to the joint position, "if the lobbyist is a law firm, it must provide information on its turnover attributable to activities that fall within the scope of the register, as well as the relative weight of each client, in accordance with a defined grid." ${ }^{\prime 5}$ The lawyer can, however, give this information on one condition: "[A] lawyer can give this information without violating his duty of professional secrecy if the lawyer (or law firm) first obtains the client's express consent." 86

In other words, lobbying clients and their interests are protected pursuant to professional secrecy unless they give their express consent to the firm to disclose their information, which they are unlikely to do so as to not be identified. The concern is that this consent requirement does not differentiate between exempt and non-exempt legal advice. This strongly implies that even in situations of non-exempt legal advice (where a lawyer is advancing a client's case with

\footnotetext{
${ }^{79} I d$. at 11 .

${ }^{80} I d$. at 12 .

${ }^{81} I d$. at 13 (emphasis added).

${ }^{82} \mathrm{Id}$.

${ }^{83}$ Dirk Van Gerven, Belgium, in Professional SECReCY OF LAWYers, supra note 73, at 55 (emphasis added).

${ }^{84}$ See the EUTR entries of Alber \& Geiger and Covington \& Burling LLP.

${ }^{85}$ Van Gerven, supra note 73, at 22 (emphasis added).

${ }^{86} I d$.
} 
regulators so as to persuade them to change a policy), the lawyer can only do so if the client expressly consents to the information being given. ${ }^{87}$

It is worth noting that the way in which the CCBE interprets professional secrecy differs from the interpretation given to the privilege and duty of confidentiality in the U.S. lobbying context. In the U.S., attorney-client privilege is broader than in many European countries, extending, for instance, to in-house lawyers' advice. Then again, the communications of lawyer-lobbyists with their clients are not usually privileged in courts: "[S] ummaries of legislative meetings, progress reports, and general updates on lobbying activities do not constitute legal advice and therefore are not protected by the attorney-client privilege." ${ }^{\prime 8}$ Importantly, the duty of confidentiality does not prevent registration and disclosure. Lawyer-lobbyists can reveal information relating to their lobbying clients and thus fulfill legal obligations under the LDA without risk of professional repercussions. Although disclosure does not require the client's consent, the American Bar Association Model Rules notes that the lawyer-lobbyist should "make sure that the client is aware of any such necessary disclosures." 89

\section{What Is Covered by the Legal Advice Exception?}

I demonstrated above how the alternating roles associated with legal lobbying require acknowledging the importance of professional secrecy. Another issue is whether lobbying services offered by the lawyer are "legal" pursuant to the definition of professional secrecy. For instance, do institutional monitoring services and the hiring of a lawyer to advance a client's case with the policymaker together qualify as defending the client's interests in law?

One way to determine whether the activities of the lawyer-lobbyist are of a "legal" nature is to return to the EUTR and to look at how its rules define legal advice. A close reading of the legal advice exception reveals two observations. First, all five activities that qualify as the provision of exempt legal advice include an explicit reference to a client, whereas in the two remaining nonexempt situations, there is no mention of a client. Second, the activities that qualify as the provision of legal advice and are excluded from the EUTR are pronouncedly neutral, expert activities, such as advice given to clients to "help them ensure that their activities comply with the relevant law," or to "better inform clients about a general legal situation," or provide information on "the potential impact of any legislative or regulatory changes." 90 These activities are not specifically targeted at EU institutions, unlike non-exempt legal advice, which is "intended to influence the EU institutions, their Members and their assistants or their officials or other staff." 91

These two qualifications, that is, client orientation and expert-neutrality, figure into the roles of the advocate and the legal expert. On the one hand, client orientation is closely associated with advice given in the advocate role. Legal advice that an advocate provides to a client, as well as the contacts he or she makes with public bodies on a client's behalf, are protected. This means that a description of the work and the communication between the advocate and the client are not intended to be disclosed to third parties or released publicly, even after the case file is closed. ${ }^{92}$

\footnotetext{
${ }^{87}$ It was not clear in the Alber \& Geiger case whether it had been the client bank that had expressly forbidden disclosure.

${ }^{88}$ Black v. Sw. Water Conservation Dist., 74 P.3d 462, 468 (Colo. App. 2003) (quoted in Ross, supra note 51, at 712 n.20). See also In re Grand Jury Subpoenas, 179 F. Supp. 2d 285 (S.D.N.Y. 2001) (quoting E. Selan Epstein, The Attorney-Client Privilege \& THE Work Product Doctrine 239 (4th ed. 2001) ("If a lawyer happens to act as a lobbyist, matters conveyed to the attorney for the purpose of having the attorney fulfill the lobbyist role do not become privileged by virtue of the fact that the lobbyist has a law degree or may under other circumstances give legal advice on matters that may also be the subject of the lobbying efforts.")).

${ }^{89}$ Model Rules of Pro. Conduct r. 1.6(b)(6) (AM. BAR Ass'N) (quoted in Ross, supra note 51, at 697).

${ }^{90}$ IIA at para. $10(1)$ (emphases added).

${ }^{91} I d$. at para. $10(3)$.

${ }^{92}$ This speaks to the argument that when blogging about the work it did for the client bank, Alber \& Geiger saw itself as providing legal expertise rather than engaging in advocacy.
} 
This strong focus on the client and the consequent emphasis on confidentiality differentiates the advocate type from the legal expert type and non-lawyer lobbyists. When academics or civil servants are called upon to give legal advice or to consider issues concerning the correct understanding and application of the law, their opinions are not given with a specific client in mind, ${ }^{93}$ and are in principle freely available in the public domain, or in some cases released to the public after the decision-making process. ${ }^{94}$ There is obviously also a strong client orientation in the work of nonlawyer lobbyists in public relations firms, but unlike the advocate type, non-lawyer lobbyists can, and frequently do, publish the work that they have done for clients on company websites.

On the other hand, neutrality and objectivity characterize the expertise and advice given in the role of a legal expert. ${ }^{95}$ As legal expert types, academics and civil servants ensure that an issue is addressed in ways that will ultimately produce a balanced and non-biased understanding of all the relevant factors affecting the decision-making process. Objectivity does not prevent the legal expert from recommending a certain course of action or interpretation, but it prevents the expert from deliberately ignoring relevant information. A similar requirement is imposed by the EUTR's Code of Conduct, which does not require lobbyists to observe their clients' interests but to provide "complete" and "non-misleading" information to decision-makers. ${ }^{96}$ The advocate, however, does not even aim at objectivity, as he or she is bound by the idea of loyalty to his or her clients. Loyalty can be termed as partisanship that "requires [lawyers] to zealously defend and advance their clients' interests." 97 An advocate thus focuses on the aspects of the legal question that will strengthen his or her client's case, often glossing over things that might possibly weaken it.

This assumption that legal expertise is value-neutral, technocratic knowledge provides lawyerlobbyists with an advantage in lobbying even when they are zealously defending their client's interests. The ability of legal language to depoliticize claims and introduce certain choices as mere technical necessities plays an important role. ${ }^{98}$ It is more convenient to lobby against a proposed measure on the basis that it will, say, hinder the free movement of goods than to claim that it will adversely economically affect a client. Successful lobbying requires that private concerns are transformed into public interests, and the lawyer-lobbyist is well equipped to do so due to the advantage inherent in the depoliticized and neutral nature of legal language.

In sum, the legal advice exception in the EUTR portrays the expertise of lawyers as neutral and objective, as well as something provided (and thus protected) in the particular circumstances of one specific client or case. This effectively means that the exception does not provide any new tools in helping to determine whether lobbying services offered by the lawyer are legal in nature. Rather, we are back to how we should understand and apply professional secrecy. As currently interpreted by the CCBE, the application of professional secrecy does not depend on the type of services the lawyer provides, or the context in which these services are delivered. Instead, by connecting registration and disclosure of lobbying activities to client permission, professional secrecy seems to provide what amounts to the carte blanche protection of lawyers against requirements under the EUTR.

\footnotetext{
${ }^{93} \mathrm{~A}$ more general question is whether the legal expert type has a client. See Peter Triantafillou, The Politics of Neutrality and the Changing Role of Expertise in Public Administration, 37 ADMIN. THEORY \& PRAXIS 176 (2015) (explaining that in Weberian thinking, it may be argued that civil servants "adopt an attitude of neutrality by which they may serve as an instrument of their political master (government) and thereby loyally work to implement political goals").

${ }^{94}$ The same principle of openness of legal advice applies in the EU, too. However, despite the endorsement of the EU Court, EU institutions have in practice opted for the secrecy of legal advice in the legislative context. See DEIRDRE CURTIN \& PÄIVI Leino-Sandberg, Openness, Transparency and the Right of Access to Documents in the EU: In-Depth AnAlysis FOR the European Parliament's Committee on Petitions (2016).

${ }^{95}$ There is an immense amount of literature on objective knowledge production by lawyers. For a foundational work, see Bruno Latour, Scientific Objects and Legal Objectivity, in LaW, AnTHropology and the Constitution of THE Social: Making Persons and Things (Alain Pottage \& Martha Mondy eds., 2004).

${ }^{96}$ EUROPA TRANSPARENCY REG., supra note 43.

${ }^{97}$ Loughrey, supra note 77 , at 737.

${ }^{98}$ Dezalay, supra note 32, at 264.
} 


\section{Possible Steps for Reform}

I am not suggesting that lawyers' policy-influencing role and engagement with public affairs services is somehow below professional dignity and not in keeping with professional standards. Legal lobbying, just like its generic counterpart, is a legitimate activity that has societal benefits. But reclaiming the legitimate potential of legal lobbying as part of the democratic decision-making system and making sure that law firms and lawyers do not end up providing a non-transparent route to decision-makers requires regulatory clarification.

First, the CCBE should reconsider its interpretation of professional secrecy in the context of the EUTR. Instead of emphasizing express client consent, it would be more in line with current transparency standards to reverse the regulatory assumption. In this form, the law firm should give the required information so long as the client has not expressly forbidden it. This would require-as is currently the case in the U.S. ${ }^{99}$ - that prior to taking on a new case, the lawyer discusses with his or her client whether the file includes elements that possibly require the disclosure of information to the EUTR. In the interests of transparency, a law firm's EUTR entry should also include nonspecified information regarding the scope of lobbying activities where professional secrecy has been invoked.

Second, more attention should be paid to the compatibility between the EUTR and the rules of national bar associations. While it is clear that the interpretation of what the CCBE calls deontological rules belongs to the bar associations, the role of lawyer-lobbyists is not an internal matter for them alone to resolve. The issue is neither that lawyer-lobbyists are unregulated by professional rules, nor that lawyer-lobbyists are left run wild under the EUTR. The issue is that these two sets of rules have not been aligned. This lack of dialogue is the key difference between the EU and the U.S. The Joint Secretariat of the EUTR and the CCBE, as an umbrella organization for national associations, should engage in a concerted effort to ensure that the lawyer-lobbyist can observe the highest level of transparency without breaching the rules of bar associations and violating the duty to protect client confidences.

What about the possibility of solving this problem through legislative intervention? The CCBE has insisted on a legally binding lobbying register, as it argues that only this can create a level playing field and enable it to communicate the duty to register to clients. The EU argues that there is no specific legal basis in the EU Treaties to enact legislation on lobbying, which is why the EUTR is based on a non-binding interinstitutional agreement between the EU institutions. As a binding register seems a distant possibility, the attention remains focused on national bar associations. Interesting in this respect is the decision of the French bar. It amended its internal rules to urge lawyers to sign up with lobbying registers at national, international and, specifically, EU levels. Under the new Article 6.2.3 of the Règlement Intérieur National (RIN), French lawyers will, if required by a public, European, or international institution's register, and if representing a client's interests to that institution, register the client's name and the amount of fees the lawyer has been paid for that representation. ${ }^{100}$

\section{F. Conclusions and Implications}

Legal lobbying is increasingly common both at the EU and national levels. As a practice, lobbying services provided by law firms is an intricate phenomenon. Lawyers who deliver lobbying services do not see themselves as lobbyists. For them, the role of a lawyer is apparently incompatible with that of a lobbyist. Even so, law firms sell services that can be characterized as having the objective of influencing legislators and regulators. Despite these new services

\footnotetext{
${ }^{99}$ Ross, supra note 51, at 697.

${ }^{100}$ CONSEIL NATIONAL DES BARREAUX, DÉCISION À CARACTÈre NORMATIF N 2015-001 PORTANT AJOUT D’Un ARTICLE 6.2.3 AU RIN SUR L'AVOCAT EXERCANT L'ACTIVITÉ DE REPRÉSENTATION D'INTERETS (June 12, 2015), available at http://encyclopedie. avocats.fr/DOCS/DCN/RIN/DCN2015-001_RIN-MODIF_2015-06-12_Art-6-2-3-Avocat-lobbyiste-ajout.pdf.
} 
marketed through law firm websites, most law firms have not signed up with the EUTR, claiming broad confidentiality concerns. Confusion also prevails at the level of regulation. The rules of the EUTR both exclude and include legal advice. The complex provision in Paragraph 10 entails both broad and specified references to legal advice, as well as two exceptions to the general exclusion of legal advice, making the application of the paragraph complicated. Given the regulatory uncertainty of what can be understood as exempt legal advice on the one hand and non-exempt advice or legal lobbying on the other hand, we are left in a situation where lawyer-lobbyists enter the decision-making process on behalf of their clients, but manage to remain in the dark as unregistered players.

Fascinatingly, this issue of lawyer-lobbying is simultaneously simple and complex. Lobbying is a regulated business, and the fact that the lobbyist works in a law firm or knows the law does not exempt the lawyer from these rules. Lawyer-lobbyists are subject to the full requirements of the EUTR, including public disclosure of information about their clients, revenues, and so on. This is not merely a question of technical compliance, as transparency is a central concern for lobbying regulation and for the legitimacy of public decision-making more generally. By withholding valuable information, lawyers may enable distance and nontransparent lobbying by allowing their clients to influence law and regulation while remaining hidden. But beneath the regulatory discussion, there are broad, complex questions concerning the lawyer-lobbyist as an actor. This Article has demonstrated how the EUTR is informed by the two lawyer roles, the "technocratic" legal expert and the "client-oriented" advocate, between which the real-life lawyer-lobbyist alternates. Through the identification of these two lawyer roles, it is possible to appreciate the value of expertise as an informational tool in the context of EU lobbying while also seeing legal lobbying as part of the established practice of providing advocacy in the service of clients' interests. But more importantly, the two ideal-type lawyer roles help illustrate the conflicting requirements that are imposed on the lawyer-lobbyist by the role of the legal expert - the source of neutral and publicly available information-on the one hand, and the advocate-privileged communications with the client-on the other hand.

The roles also help identify the two key issues associated with the role and regulation of the lawyer-lobbyist. The first is whether professional secrecy extends to lobbying services offered by law firm lawyers. I demonstrated that the current interpretation by the CCBE of professional secrecy means that a law firm can disclose its activities, including those which fall outside the legal advice exception, only when the client expressly consents to disclosure. Such an interpretation seems misinformed because it overlooks the crucial qualification that links professional secrecy to legal activities. The second issue relates to what is meant by legal activities. The EUTR does not exclude legal activities from its scope simply because lawyers know the law, have a law degree, or happen to work in a law firm. It does so in situations when the activities of the lawyer fall within the legal advice exception. The exception is ambiguous and difficult to apply. But crucially, the exception portrays legal advice as neutral and objective as well as something provided with respect to the particular circumstances of one specific client, a specific case, or a contract, thereby bringing it under professional secrecy. This provides the lawyer-lobbyist with grounds for refusing to publicly acknowledge its role as a lobbyist. The ball is now in the legal profession's court to ensure that legal lobbying does not give rise to the creation of a shadow market of public affairs where the legal profession constitutes a non-transparent avenue to law and policy-making.

This Article also offered an insight into the changing role of the lawyer in the 21 st century EU and into the ways in which the legal profession redefines professional privileges, such as professional secrecy, in the era of increased transparency. Some steps have already been taken by the legal profession to provide a reinterpretation of professional secrecy in the context of 
the EU's money laundering rules. ${ }^{101}$ Yet the discussion about professional secrecy and legal lobbying is more fundamental because it involves a discussion about the growing role of lawyers in public policy-making and how the established deontological rules of the profession fit this policy-influencing role.

In that spirit, this Article represents a first attempt at conceptualizing and assessing the role and regulation of lawyer-lobbyists in the EU. Further research is required to shed light on, for instance, where lawyer-lobbyists, during the course of their everyday activities, draw the line between the provision of legal advice and lobbying; how lawyers working in political consultancy firms deal with professional rules and traditional values of the legal profession; how legal lobbying plays out in different fields of law, in different occupational roles such as in-house legal counsel or legal advisor to a NGO; and how different legal and ethical rules perceive legal lobbying in EU Member States, or in other jurisdictions such as in the U.S. and Canada, and so on.

One can, of course, still ask whether there really is such a thing as a lawyer-lobbyist. Are the roles of the lawyer and the lobbyist compatible enough to mix? My response is a reserved "yes," because the outlines of a lawyer-lobbyist are difficult to discern. The key features of this oscillating movement between the two roles is that, first, unlike non-lawyer counterparts, lawyer-lobbyists present their knowledge to the decision-maker mainly as a legal expert and recode clients' policy interests into the technocratic language of law. The second feature is that, once again, unlike nonlawyer counterparts, they prevent the disclosure of the details of lobbying work under the EUTR regime by redefining it as advocacy to which professional secrecy applies. In the first case, lawyerlobbyists distance their clients from the policy-making process by providing seemingly general technical legal expertise. In the second case, they bring clients into a zone of anonymity that conventional lawyering services provide. This win-win is, I conclude, essentially what distinguishes the lawyer-lobbyist as a unique actor, in relation to both the typical lobbyist and the conventional lawyer.

In terms of transparency and the public perception of the legal profession, the situation is nevertheless far from ideal or beneficial. The tension between transparency and the rules of professional secrecy has the potential to negatively affect the legitimacy of legislative and decisionmaking processes and to become a liability rather than a policy and business advantage for the profession. The legal profession needs to address this tension and to engage in efforts to resolve it more seriously than it has thus far.

\footnotetext{
${ }^{101}$ For an elaboration of the issue, see Michaud v. France, App. No. 12323/11 (Dec. 6, 2012), http://hudoc.echr.coe.int/eng? $\mathrm{i}=001-115377$, on the obligation of French lawyers to report their suspicions regarding possible money laundering activities by their clients. The applicant, a member of the Paris Bar and the Bar Council, submitted that this obligation, which resulted from the transposition of European directives - these directives having since been replaced by Directive (EU) 2015/849 of the European Parliament and of the Council of May 20, 2015 on the prevention of the use of the financial system for the purposes of money laundering or terrorist financing-was in conflict with Article 8 of the Convention, which protects the confidentiality of lawy-erclient relations. The Court held that no violation had taken place. While stressing the importance of the confidentiality of lawyer-client relations and of legal professional privilege, it considered that the obligation to report suspicions pursued the legitimate aim of prevention of disorder or crime. It held that the obligation to report suspicions did not interfere disproportionately with legal professional privilege, because lawyers were not subject to the above requirement when defending litigants and the legislation had put in place a filter to protect professional privilege, thus ensuring that lawyers did not submit their reports directly to the authorities, but to the president of their bar association.
}

Cite this article: Korkea-aho E (2021). Legal Lobbying: The Evolving (But Hidden) Role of Lawyers and Law Firms in the EU Public Affairs Market. German Law Journal 22, 65-84. https://doi.org/10.1017/glj.2020.97 